\title{
Autism spectrum disorder and beta thalassemia minor: A genetic link?
}

\author{
Hamza Ayaydın, Hatice Takatak \\ Department of Child and Adolescent Psychiatry, Harran University Faculty of Medicine, Şanluurfa, Turkey. \\ E-mail: drhamzaayaydin@yahoo.com \\ Received: 18th July 2017, Revised: 18th August 2017, Accepted: 17th September 2017
}

SUMMARY: Ayaydın H, Takatak H. Autism spectrum disorder and beta thalassemia minor: A genetic link? Turk J Pediatr 2018; 60: 443-445.

Autism spectrum disorder (ASD) is characterized by persistent deficits in social interaction and communication, and by restricted and repetitive patterns of behaviors and interests. Beta-thalassemia minor (BTM) is a common genetic blood disorder in Turkey. BTM is a single-gene disease that causes a decrease in beta globin production. We describe a girl aged 4 years and 4 months referred to our department due to speech delay, inability to establish social communication and overactivity. She was diagnosed with ASD according to DSM-5 criteria and Beta-thalassemia minor. Although there have been case reports of BTM with the some psychiatric conditions, to the best of our knowledge there are none concerning comorbid ASD and BTM. The aim of this report is to describe a possible genetic association between ASD and BTM since they have a common link associated with chromosome 11 .

Key words: autism spectrum disorder, beta thalassemia minor, genetic, child.

Autism spectrum disorder (ASD) is a neuropsychiatric disorder characterized by persistent deficits in social interaction and communication, and by restricted and repetitive patterns of behaviors and interests. ${ }^{1}$

Beta-thalassemia minor (BTM) is a common genetic blood disorder in Mediterranean countries, such as Turkey. BTM is a single-gene disease that causes a decrease in beta globin production and is frequently asymptomatic. Since it can cause mild microcytic hypochromic anemia it is frequently identified after blood count is performed for other reasons. ${ }^{2,3}$

At laboratory testing, hemoglobin values are slightly low, with a decrease in mean erythrocyte volume ( $\mathrm{MCV}<80 \mathrm{fL}$ ) and mean erythrocyte hemoglobin $(\mathrm{MCH})$ levels. In contrast to iron deficiency, erythrocyte numbers are normal or increased. At hemoglobin electrophoresis, hemoglobin A2 (>3.5\%) and/or hemoglobin F $(2-10 \%)$ are mildly elevated. Beta-thalassemia minor is a common and mostly symptomless disease and does not require treatment. ${ }^{4}$

Chromosome 11 has been implicated as being associated with psychiatric disorders such as attention deficit hyperactivity disorder (ADHD),
Tourette syndrome, schizophrenia, and bipolar disorder. ${ }^{5-7}$ These psychiatric disorders are more common in patients with autism compared to the normal population. Genetics also play an important role in autism. The hemoglobin beta gene is located at 11p15.5. There have been reports suggesting that ASD is associated with the 11 p15.5 location. ${ }^{8}$

Although there have been case reports of BTM with the above psychiatric conditions, to the best of our knowledge there are none concerning comorbid ASD and BTM. The aim of this report is to describe a possible genetic association between ASD and BTM since they have a common link associated with chromosome 11.

\section{Case Report}

A girl aged 4 years and 4 months was brought to our clinic by her family due to speech delay, inability to establish social communication and overactivity. At psychiatric evaluation, the patient made limited eye contact, did not look when called by name, did not obey verbal commands, did not engage in non-verbal behavior such as gestures or facial expressions, 
exhibited inadequate emotional and social interaction and did not share her interests and successes. She was not toilet trained and was able to form only simple two-word sentences. She did not play games with age-appropriate themes, exhibited stereotypic behavior such as clapping and was intensely interested in spinning objects (such as a washing machine agitator). Her developmental level was assessed using the Ankara Developmental Screening Inventory (ADSI). ${ }^{9}$ Her age equivalence was 19 months at the global development level, 17 months at the linguistic-cognitive level, 22 months in terms of fine motor skills, 23 months in terms of gross motor skills and 20 months in terms of socialization/self-care. The Turkish versions of the Autism Behavior Checklist $(\mathrm{ABC})^{10}$ and the Childhood Autism Rating Scale (CARS) ${ }^{11}$ were used to evaluate the severity of her autistic symptoms. Her total scores were 88 on the $\mathrm{ABC}$ and 46 on the CARS (indicating severe autism). Blood biochemistry tests, urinalysis, audiometry, thyroid function tests, brain magnetic resonance imagery, electroencephalography and abdominal ultrasound were all normal. Blood tests values were HGB: $9.564 \mathrm{~g} / \mathrm{dl}$ (normal range 12-18.1 $\mathrm{g} / \mathrm{dl}$ ), MCV: $57.08 \mathrm{fL}$ (normal range 80-97 fl) $\mathrm{MCH}$ : $14.84 \mathrm{pg}$ (normal range 25-33.5 pg), and RBC: $6.44410^{6} / \mathrm{mm}^{3}$ (normal range $4.06-4.6910^{6} / \mathrm{mm}^{3}$ ). Serum iron, unsaturated iron binding capacity (UIBC), ferritin, B12 and B9 levels were normal. BTM was diagnosed on the basis of an HBA2 value of 4.8 (normal range $<3 \%$ ) and an HBF value of 0.6 (normal range $<1 \%$ ) at hemoglobin electrophoresis.

The patient was diagnosed with ASD and global developmental delay according to DSM5 , and with BTM. She was referred for special education.

An informed consent was received from the patient's father

\section{Discussion}

We present a case of a child diagnosed with ASD, a neurodevelopmental disorder, and also with BTM. It is possible that having BTM was an incidental finding or that this disorder had played a contributory role in the development of autism. Multiple genetic factors and genetic-environmental interactions are implicated in the etiology of autism.
Chromosome regions and genes associated with autism have been identified through genome screening, association analysis and candidate gene analyses. Associations have been identified in different chromosomal regions, with eight being particularly important $(2,3,7,11,15$, 17, 22 and $\mathrm{X}$ chromosomes). ${ }^{12,13}$

Chromosome 11 is thought to be associated with several psychiatric disorders, including impulse control disorders, bipolar disorder, ADHD and Tourette's syndrome. ${ }^{6}$ ADHD and tic disorder are more common in ASD compared to the normal population. There are reports a positive association between autism and the locus containing the gene for HRAS1 (c-Harvey-ras-1) $)^{8,14}$. The HRAS- 1 and beta globin genes are located at $11 \mathrm{p} 15.5 .^{15}$

No studies to date have investigated the prevalence of beta thalassemia in ASD patients. The presence of chromosome 11, one of the genes linked to autism, in the region containing the $ß$-globin gene, responsible for BTM, suggests that there may well be a genetic association between the two disorders. The limitation of this manuscript is that no chromosomal analysis was performed. Our scan of the literature revealed no reports of a probable genetic association between thalassemia minor and autism. To the best of our knowledge, this case study is the first to discuss such a possible link. Further studies are now needed to support this study.

\section{REFERENCES}

1. American Psychiatric Association. Diagnostic and Statistical Manual of Mental Disorders. (5th ed). Arlington, VA: American Psychiatric Association Publishing, 2013: 50-59.

2. Damon LE, Andreadis C, Linker. CA Blood disorders. In: Papadakis MA, McPhee SJ (ed). Current Medical Diagnosis andn Treatment ( $52^{\text {nd }}$ ed). New York: Mc Graw Hill, 2013: 494-496.

3. Benz EJ. Disorders of hemoglobin. In: Longo DL et al (ed). Harrison's principles of internal medicine (18th ed). New York: Mc Graw Hill, 2012: 858-861.

4. Keşkek SO, Kirim S, Turhan A, Turhan FG. Depression in subjects with beta-thalassemia minor. Ann Hematol 2013; 92: 1611-1615.

5. Toufexis M, Lewin AB, Storch EA, DeOleo C, Murphy TK. A possible link between tic disorders associated with beta thalassemia minor and sickle cell disease. J Clin Case Rep 2013; 3: 244.

6. Borras L, Huguelet P. Schizophrenia and betathalassemia: A genetic link? Psychiatry Res 2008; 158: $260-261$. 
7. Hosseini SH, Saravi WG, Hashemi-Soteh SMB, Zarghami M, Saljughian A. Evaluation of co-segregation between bipolar mood disorder and heterozygous beta-thalassemia in patients originated from Iran. Res J Biol Sci 2008; 3: 798-800.

8. Hérault J, Petit E, Martineau J, et al. Autism and genetics: Clinical approach and association study with two markers of HRAS gene. Am J Med Genet 1995: $60 ; 276-281$.

9. Savasir I, Sezgin N, Erol N, Ankara Gelişim Tarama El Kitabı (1st ed.). Ankara: Türk Psikologlar Derneği, 1994: (in Turkish).

10. Yılmaz Irmak T, Tekinsav Sütçü S, Aydın A, Sorias O. Otizm davranış kontrol listesinin (ABC) geçerlik ve güvenirliğinin incelenmesi. Çocuk ve Gençlik Ruh Sağlı̆̆1 Dergisi 2007: 14; 13-23.
11. Sucuoğlu B, Öktem F, Akkök F, Gökler B. Otistik çocukların değerlendirilmesinde kullanılan ölçeklere ilişkin bir çalışma. 3P Dergisi 1996: 4; 116-121.

12. Yüksel A. Otizm Genetiği. Cerrahpaşa Tıp Dergisi 2005: 36; 35-41.

13. Miles JH. Autism spectrum disorders-A genetics review. Genet Med 2011: 13; 278-294.

14. Hérault J, Perrot A, Barthélémy C, et al. Possible association of c-Harvey-Ras-1 (HRAS-1) marker with autism. Psychiatry Res 1993: 46; 261-267.

15. Harada H, Nakajima T, Inazawa J, Abe T. Bipolar affective disorder associated with beta-thalassemia minor. Biol Psychiatry 1995: 37; 477-479. 